\title{
Sociodrama: strategy for nurses' self-reflection on blindness
}

\author{
Sociodrama: estratégia para autorreflexão de enfermeiros sobre a cegueira
}

Inacia Sátiro Xavier de França ${ }^{1}$, Francisco Stélio de Sousa ${ }^{1}$, Ana Paula Andrade Ramos ${ }^{1}$, Fabiana Coriolano Ribeiro Cavalcante $^{2}$, Cibely Freire de Oliveira ${ }^{3}$

Objective: to investigate the master students' expressions about feelings, difficulties and challenges arising from participation in sociodrama "as if" they were blind. Methods: qualitative study. Participants were eight Master students in nursing. They used sociodrama, a video recorder and the Content Analysis technique. In implementing the sociodrama, the steps were followed were warm-up, drama, comments and theoretical processing. Results: the following thematic categories emerged: the role as blind person triggering limitation, blocking and fear; the role as blind person triggering a confused notion of one's own body; spontaneity and creativity expressed by Master students. Conclusion: the Master students expressed the feeling of fear to walking in an environment with which they were already familiar, had difficulty in eating because of the confused notion of their own body, and could reflect on the challenge of caring for the blind person, because they realized that they were professionally unprepared to take care of these individuals.

Descriptors: Blindness; Nursing; Health Education; Psychodrama.

Objetivo: investigar as autoexpressões de mestrandas acerca dos sentimentos, dificuldades e desafios decorrentes da participação em sociodrama "como se" fossem cegas. Métodos: estudo qualitativo. Participaram oito mestrandas em enfermagem. Utilizaram-se sociodrama, uma filmadora e Análise de Conteúdo. Na execução do sociodrama, foram seguidas as etapas de aquecimento, dramatização, comentários e processamento teórico. Resultados: emergiram as categorias temáticas: 0 papel de cega desencadeando limitação, bloqueio e medo; 0 papel de cega desencadeando uma noção confusa do próprio corpo; A espontaneidade-criatividade manifestada pelas mestrandas. Conclusão: as mestrandas expressaram o sentimento de medo ao se mobilizarem em ambiente com o qual já estavam familiarizadas, tiveram dificuldade para se alimentar devido à noção confusa do próprio corpo, e puderam refletir acerca do desafio que é cuidar da pessoa cega, pois perceberam que, profissionalmente, estavam despreparadas para cuidar destes indivíduos.

Descritores: Cegueira; Enfermagem; Educação em Saúde; Psicodrama.

\footnotetext{
${ }^{1}$ Universidade Estadual da Paraíba. Campina Grande, PB, Brazil.

${ }^{2}$ Centro Integrado de Saúde Amaury de Medeiros. Recife, PE, Brazil.

${ }^{3}$ Faculdade Paschoal Dantas. São Paulo, SP, Brazil.
} 


\section{Introduction}

Nowadays the issue of disabled person has been frequently discussed in the media. The causes of this approach include urban violence, for being which most affects the physical integrity of young people able to work, and the sanction, by the State, of legal postulates that ensure citizenship rights to people with disabilities.

In the case of blind people, there are about 314 million people with visual impairment around the world, among which 45 million are blind ${ }^{(1)}$. In Brazil, approximately 35.7 million people have visual difficulties, and Paraiba state has 672,400 people with some difficulty in seeing; 142,200 people with great difficulty; and 8,500 blind people ${ }^{(2)}$.

Blindness is understood as visual acuity worse than $20 / 400$ and low vision as visual acuity worse than $20 / 60$ in the better eye ${ }^{(3)}$. The impact of this deficiency is exemplified with: functional impairment, limitation and restriction of participating and performing daily activities, as well as impairment of independence and autonomy of respondents ${ }^{(4)}$, and lack of financial resources, physical safety and protection, of transport and dependence on medication or treatments, among others $^{(5)}$.

Thus, among the difficulties that these people face, there is highlight to the inability to access information, limitations in motor, cognitive and social development and in communication skills ${ }^{(6)}$.

In addition to the social commitment to the inclusion of the blind people, it is appropriate to state that the inclusion of people with any type of disability requires that health professionals from different healthcare levels acquire knowledge, skills and attitudes so that they can approach these people an appropriate manner ${ }^{(7)}$.

This implies that the training of qualified human resources to care for people with disabilities must be one of the attributions of higher education institutions through the inclusion of elective components that address disability in the pedagogical project of the courses of all professions whose field of knowledge relates to the care of any needs of these people. Furthermore, once working in the health system, professionals need continuing education to keep updated with the advancement of science and assistive technologies to help these people to become independent and autonomous.

This context underlies the guiding problem of this study: there are few higher education institutions that have already entered a component targeted to care for people with disabilities in the Pedagogical Project of Undergraduate Nursing Course. The lack of training of some nurses to care for people with disabilities is one of the factors contributing to that blind people face challenges in health.

The study is justified due to the progressive increase of visually impaired people in the country, the small number of nurses working in this area of care and the small number of researchers interested in this topic. Also because the transforming power of sociodrama enables the expansion of the participants' view into themselves and their reality ${ }^{(8)}$.

The use, in sociodrama, of formal education content by observing the group in an educational perspective by and for action ${ }^{(9)}$ reinforced the relevance of the study, since it generated selfknowledge and professional experience by exploring the Masters students' capability in face of their limitations in caring for blind people.

In view of the above, the question that guided the study was: what feelings, difficulties and challenges related to the experience of blind person can be expressed by nursing master students after attending a sociodrama? To answer this question, authors aimed to investigate the Master students' expressions about feelings, difficulties and challenges arising from participation in a sociodrama "as if" they were blind. 


\section{Methods}

This is a qualitative study, conducted from July to December 2013 in a public higher education institution in the Northeast of Brazil. Participants were eight Master students regularly enrolled in the Master in Nursing of this higher education institution, who in 2013.2 were attending the component "Health Education and Nursing: approach perspectives" and who agreed to participate in a dynamic on the subject "blind person" as activity of the research project "Evaluation of functional capacity and self-care in blind people".

The basic theory in this study was socionomy ${ }^{(10)}$, a psychosociological construct created in the early twentieth century for the study of the laws governing the social and group behavior. This theory has three specific axis: 1 - sociatry, for the creation of methods for use with social groups, aiming at the minimization of conflict and the promotion of group communication. Its main methods are: psychodrama, sociodrama, axiodrama and spontaneous theater. In the specific case of sociodrama, the main purpose is the training and role playing encouraging spontaneity and creativity to better experience the reality from the recognition of the other. 2 - sociodynamics, directed to the study of the dynamics of social relations and the functioning of the groups through the interpretation of the roles developed in group experiences. The following concepts are highlighted in this axis: action, meeting, game, roles. 3 - sociometry offers models of sociometric tests for measurement of interpersonal relationships. Through the diagram of the socialaffective relations, the tests provide an understanding of the group structure ${ }^{(10)}$.

The method chosen was the sociodrama, as it enables addressing a common theme to a group, taking as focus the common social situation shared for several subjects in order to evaluate intergroup relations, its conflicts and sufferings, aiming to provide the contact of actors with each other and with themselves, questioning the "cultural conserve" (cultural values preserved in various forms: rituals, ceremonies, standards, among others) to develop the sensitivity and critical ability to understand and transform reality. Thus, the sociodrama is characterized by learning and by training roles $^{(10)}$, which is why this was the ideal pedagogical strategy for this study, enabling Master students to awaken the spontaneity-creativity complex, essential to deal with situations involving the blind person.

The sociodrama happened in the Master of Nursing classroom, located on the second floor of the classrooms center of the higher education institution selected for this study. Access to the building can be done by stairs or elevator. The room was equipped with chairs, air conditioning, notebook, display projectors, projection screen and a video recorder. Near the projection screen, the researchers placed a table containing a breakfast for participants.

In implementing the sociodrama, the steps were followed ${ }^{(10)}$ :

Step 1 - Warm-up: In the morning, at nine o'clock, the Master students were received by two professors of the component "Health education and nursing: approach perspectives" in the building lobby where the classes take place in the Masters. It was the fifth class, so students were already familiar with each other, which avoided estrangement. Then, an informal chat was developed about the experience of blind people, highlighting their difficulties in access to health goods and services, and architectural and attitudinal barriers to which they are submitted. In the next step, the Master students were consulted on that day the class be given in the form of a sociodrama in which they would participate "as if" they were 
blind. After the proposal was accepted, we moved to the next step.

Step 2 - Dramatization: The Master students were blindfolded and, with the help of one of the teachers, were conducted by stairs equipped with handrails from the hall to the first floor. Next, they moved by elevator from the first to the second floor to access the classroom. In the classroom, with the Master students standing at the center in the middle of the room, we proceeded to a stretching, whose movements were suggested by one of the teachers. Then, a breakfast with healthy foods was offered to the students and they were guided on the provision of food, plates, cutlery and glasses so they could serve themselves. After the end of the meal, the Master students settled in chairs placed in a semicircle. The blindfolds were removed. It is worthy mentioning that because the participants were blindfolded the video recording did not influence the performance of the role as a blind person.

Throughout this process of dramatization, which lasted about three hours, the observer used a Nikon camera, given the need to capture, with increased reliability, details of the dramatic action, its intensity and speed with which students acted, governed by permission and spontaneity. The capture of these aspects, ensured by video recording, would be difficult to control by the researcher if other resource or tool was used ${ }^{(10)}$.

Step 3 - Comments: feelings and identifications with the theme dealt were shared in informal conversation occurred in Step 1. The teachers encouraged the group to think about the emotions, difficulties and challenges that the experience of acting "as if" they were blind had provided to them during the sociodrama.

Step 4 - Theoretical Processing: The whole drama filmed by the observer was treated by using content analysis technique ${ }^{(11)}$ that was developed in three phases: a) Typing in full of all the lines of Master students, registered by the video recording. Seizure of the main ideas and their meanings through floating reading, followed by exhaustive reading and meaningful text clippings to the analytical process. b) Material exploration, at which the cut lines of text units were grouped according to the meaning cores inherent to them. Then, the groups of lines were coded and categorized thematically. c) There was the processing of results through interpretative analysis of the categories and discussion with the relevant literature.

In interpretative analysis of the categories there were the steps of inference and interpretation, such as possibilities of seizure of manifest and latent meanings contained in the empirical material ${ }^{(11)}$, comparing the results with those of other researchers who have studied the subject. Anonymity was assured by identifying them with the letter "M" for Master's degree, followed by a numeral in ascending order: M1, M2 ... M8.

The study complied with the formal requirements contained in the national and international regulatory standards of research involving human beings.

\section{Results}

Figure 1 shows the verbalization of the dramatic experience dealing with the role of blind person triggering limitation, blocking and fear.

In Figure 2 the participants relate the dramatic experience with the confused notion of their own body.

Figure 3 shows the manifestation of spontaneity-creativity of Master students after participating in the sociodrama. 


\begin{tabular}{|c|c|}
\hline Deponents & Verbalization of dramatic experience \\
\hline M1 & $\begin{array}{l}\text { It was very difficult to climb stairs, get here. We walked in a group, but I still did not trust. I was very scared. I did not trust } \\
\text { completely and I think one of the things that was most difficult was talking. I wanted sometimes to speak, but as I could not } \\
\text { see, I do not know why, I could not talk. I could not. I kept waiting for the other end. I could not see if the other had finished. } \\
\text { Even though I could listen, I could not talk. So it was very difficult for me. }\end{array}$ \\
\hline M2 & $\begin{array}{l}\text { I was silent all the time. It feels like you're not participating in things, you cannot know the time to talk, cannot know if you } \\
\text { can talk, if people are paying attention to you. It's a bad feeling. }\end{array}$ \\
\hline M4 & $\begin{array}{l}\text { I felt fear, especially in the elevator. I was kind of scared. I got that feeling that the door could close. I was listening that little } \\
\text { noise, but the worst thing was to get in and out of the elevator. I was afraid of colliding, falling, hurt myself, fear of space, I did } \\
\text { not know where everything was, where the wall was, the door, fear of bringing something down. I was very afraid. }\end{array}$ \\
\hline M5 & $\begin{array}{l}\text { It was as if I had a kind of lock that told me: you cannot leave go anywhere. I was directionless. The truth is this: I did not } \\
\text { know where to go. }\end{array}$ \\
\hline M6 & $\begin{array}{l}\text { Since I put the blindfold, I began to get... I don't know what. My impression is that I could not get out because if I took a step, I } \\
\text { would fall. I tried to sharpen my vision, my hearing and then I found myself bending my head to listen the voice of the people } \\
\text { more clearly, noting that the door slammed, to the person who was talking. And then I lifted my head up and understood why } \\
\text { I see the blind people make that move on television. }\end{array}$ \\
\hline
\end{tabular}

Figure 1 - The role as blind person triggering limitation, blocking and fear

\begin{tabular}{|c|l|}
\hline Deponents & \multicolumn{1}{c|}{ Verbalization of dramatic experience } \\
\hline M4 & $\begin{array}{l}\text { I got all dirty. I had to know the size of the fruits by picking up and feeling with the hands to associate, to know what kind of } \\
\text { fruit I would eat. I found it difficult. }\end{array}$ \\
\hline M5 & $\begin{array}{l}\text { I was not able to combine the movement of the hand with a fork, as touching the mouth, so I touched my nose. Living with } \\
\text { blindness must be very difficult. }\end{array}$ \\
\hline M7 & $\begin{array}{l}\text { For me, it was hard to eat without being able to see. I did not know where things were, the fruit, but from the moment the } \\
\text { researcher said that this is melon, here is the table and I groped the table and saw where the dishes were, I managed to do it. } \\
\text { Only the cake, it crumbled when I cut it. Then I could understand how it is to be blind. }\end{array}$ \\
\hline
\end{tabular}

Figure 2 - The role as blind person triggering a confused notion of one's own body

\begin{tabular}{|c|c|}
\hline Deponents & Verbalization of dramatic experience \\
\hline M3 & $\begin{array}{l}\text { I wonder what blind people need to overcome to change this bad thing. Even though they can overcome, I think they have } \\
\text { moments when they feel bad again, don't they? And then they need help, support from their friends, from health professionals } \\
\text { to help overcoming this and this overcome capacity depends largely on the inner strength that is revived in this conviviality. }\end{array}$ \\
\hline M5 & $\begin{array}{l}\text { The first thing that comes to mind is how can I, in an exercise practice, talk to a blind person: lift the arm, bend the forearm, } \\
\text { so that they can easily understand the exercise? How am I supposed to address quality of life, how can I address health } \\
\text { education in a simple manner? Our care practice needs to improve, we need to apply humanization. }\end{array}$ \\
\hline M8 & $\begin{array}{l}\text { I have been a nurse for many years and I want work with another group of people with limitations, which today was the } \\
\text { visual impairment, to see whether or not I am prepared to deal with this group of people in the health unit, in a hospital. Are } \\
\text { we ready? We are not talking about quality of life, we are talking about lifestyle, bringing to our practices. I want us to leave } \\
\text { this sociodrama with this reflection because I felt too much difficulty. }\end{array}$ \\
\hline M3 & $\begin{array}{l}\text { Before, I have always tried to walk in the dark, I turned off the light and tried to walk because I always thought that if I got } \\
\text { blind, not that I will ... we are vulnerable to diabetes, hypertension, and finally to the urban violence itself. So, this experience } \\
\text { was very rich for us to put us in the other's place, wasn't it? To think how to help the blind person in their demands. }\end{array}$ \\
\hline
\end{tabular}

Figure 3 - Spontaneity-creativity expressed by Master students 


\section{Discussion}

The role-play by Master students "as if" they were "blind" was evident in the categories discussed. It was found in the cuts of lines that the experience of the dramatization of an unknown situation is a source of insecurity and anxiety, as it involves a specific and differentiated emotional charge. In the case of Master students of this study, the fear of the unknown was the main cause of insecurity and anxiety, being experienced in a dramatic and frightening way.

In the dramatic situation experienced by Master students, the focus of the difficulties imposed by the blindfolds was significant, which contributed to the emergence of a fearful and insecure self, by finding the breaks of the academic training and the limits to be overcome in concerning to take care of the blind person. Thus, the feeling of fear is referred to as a blockage, a crippling and silencing limitation. These sensations perceived by Master students approach the results of this study to those resulting from other research conducted in a public hospital in Rio de Janeiro, Brazil, to determine the social representations of nurses about the care of people with human immunodeficiency virus/acquired immunodeficiency syndrome, which evidenced that fear was expressed as the feeling of unpreparedness, professional insecurity and lack of scientific information ${ }^{(12)}$.

Insecurity also happened in a study conducted in Montevideo, Uruguay, attended by nine nurses working in both public and private hospitals. The study reports that nurses realized the gap between theory and practice permeating professional performance, causing insecurity to take over the management of care, besides the desire to seek formal and informal knowledge, with expectations of establishment of specific functions, autonomy and professional identity ${ }^{(13)}$.

It is worth mentioning, also, that, in the current study, the temporary deprivation of vision and locomotion in a space, although it was familiar, gave to Masters students a sense of vulnerability, which dulled the knowledge of the most appropriate initiatives to challenge it, resulting in negative expressions that showed a pessimistic view of the condition of being a "blind person". For them, fear was manifested as the personal fear of making mistakes and lack of confidence in relation to the environment. This fear was so intense that took the form of isolation, blocking of speech, immobility, suffering.

Correlated literature research, anchored in psychoanalysis, which aimed to discuss what scares in the body, has shown that a suffering body points limit and remodels itself from the change that the person suffers before their image, their self ${ }^{(14)}$. Thus, in addition to spatial mobility difficulty, the fact that the participants act "as if" they were "blind", and feel fear, influenced negatively motor coordination, so that the personal resourcefulness was harmed during the meal. This phenomenon is also explained in another study in which the authors explain that all movements are based on postural balance and this is influenced by the sensory systems: visual, vestibular and proprioceptive. Therefore, deprivation of any of these systems may have important consequences for the postural balance and consequently for the motor development ${ }^{(15)}$.

This assertion is corroborated by a study conducted at rehabilitation clinic in São Paulo, Brazil, aiming to describe the neurological, psychological, motor and visual development of visually impaired children $^{(16)}$. Participants were 30 children in the control group and 15 in the experimental group. Authors used the table of the American Foundation for the Blind to assess functional vision, and the results showed that most children in the control group had inappropriate behavior of coordination, and that children with visual impairment were characterized by presenting global developmental delay, particularly in the behavior of coordination ${ }^{(16)}$.

Despite the distinct object and research methods in the aforementioned study, it is reiterated that the results of the current study approach those of the research in São Paulo ${ }^{(16)}$, since the results indicate that the lack of vision contributed to change in locomotion and motor coordination. 
In another study of 13 people with physical or sensory disabilities practicing water sports in a sports park, researchers found that maintaining safe environment and mobilization were the most affected life activities ${ }^{(17)}$. In the current study, participants in the role of blind person also had impaired mobility and the feeling of being in unsafe environment. The confused notion of one's own body experienced by Master students makes inference to the results of that study. Apart from that, the fact that they were blindfolded contributed to the reflection that blind people have peculiar needs of their condition.

Based on the Master students' speech, it is evident that health relationships need to be based primarily on the relationship between people and constantly updated and trained professionals, so that the care for the blind people is rethought. In this perspective, among the conditions of professional unpreparedness evoked by Master students, there is a fundamental element to be highlighted in this experience that was the spontaneity-creativity expressed by these participants, based on the sharing of feelings and the identification of gaps in their professional performance. For Master students, the sociodrama was a positive experience because the strangeness experienced to behave "as if" they were "blind" unveiled the gaps in their own professional performance. And by feeling insecure, they understood that they need to acquire skills to care for the blind person.

This same understanding was expressed by the authors of a study with 15 family members responsible for children/adolescents with special health care needs, attended in specialties outpatient clinic. Corroborating the results of this research, it was evidenced the need for training of the nursing team, in the perspective of more active participation in health teams, and empowerment of caregivers, guiding them about the home activities, in addition to providing guidance, emotional support and care to users' families $^{(18)}$.

In this sense, people with disabilities are users with diverse health needs, lacking specialized services and qualified multidisciplinary team to meet their demands through interdisciplinary care for them and for their families ${ }^{(19)}$.

From the foregoing, it is understood that the theatrical interpretation gives the actor awareness that they have a body, a mind and an intertextual competence. The actor realizes that it is in their own body that they experience the show It is thanks to this perception that they live, understand and respond to the spectacle. The Master students realized, experienced and reacted to the show ${ }^{(20)}$. Thanks to this catharsis, the Master students were able to understand objectively certain circumstances and situations experienced by people with visual impairment and became aware of how they would feel if they were in the place of these people. This phenomenon shows that the use of sociodrama contributes to the development of creative-spontaneous skills, promoting the development of sensitivity and self-knowledge.

This study has limitations: small number of participants, which prevents generalizations. The sociodrama occurred in a single moment. A longitudinal research, with the same group, would enable to analyze the cognitive, affective and behavioral aspects of spontaneity-creativity over time. Furthermore, it was not found in the consulted databases updated articles dealing on the subject so that it could be made approximations or distancing of the results of this study with those of other researchers, a fact that prevented greater breadth and depth of results. The goal was achieved, however, it is understood that there is need for further research focusing on other aspects, in order to contribute to improving the quality of life of this social segment.

\section{Conclusion}

Through the experience of being "blind person", the Master students of this study expressed the feeling of fear walking in an environment with which they were already familiar, had difficulty in eating because of the confused notion of the body, and could reflect on the challenge of taking care of blind people, 
because they realized that, professionally, they were unprepared to take care of these individuals.

It was concluded that nurses need to know the limitations of blind people to plan and develop health education actions, to help them preserve the functional capacity, compensate for the loss of a function or a functional limitation and facilitate social adjustment or readjustment.

\section{Collaborations}

Franca ISX, Sousa FS, Ramos APA, Cavalcante FCR and Oliveira CF contributed to the design, analysis and interpretation of data, relevant critical review of the intellectual content and final approval of the version to be published.

\section{References}

1. World Health Organization (WHO). World report on diability. [Internet]. 2011 [cited 2016 may 14]. Available from: <http://www.who.int/ disabilities/world_report/2011/en/index.html

2. Instituto Brasileiro de Geografia e Estatística. Censo Demográfico 2010: características gerais da população, religiões e pessoas com deficiência. Rio de Janeiro: IBGE; 2010.

3. Couto Júnior A, Oliveira LAG. The main causes of blindness and low vision in school for blind. Rev Bras Oftalmol. 2016; 75(1):26-9.

4. Silva MR, Nobre MIRS, Carvalho KM, Montilha RCI. Visual impairment, rehabilitation and International Classification of Functioning, Disability and Health. Rev Bras Oftalmol. 2014; 73(5):291-301.

5. Rebouças CBA, Araújo MM, Braga FC, Fernandes GT, Costa SC. Avaliação da qualidade de vida de deficientes visuais. Rev Bras Enferm. 2016; 69(1):72-8.

6. Hernández C, Pedraza LF, López D. Dispositivo tecnológico para la optimización del tiempo de aprendizaje del lenguaje Braille en personas invidentes. Rev Salud Pública. 2011; 13(5):865-73.

7. Maia ER, Pagliuca LMF, Almeida PC. Learning of community health agent to identify and register disabled people. Acta Paul Enferm. 2014; 27(4):326-32.
8. Massaro G. Cinema, subjetividade e psicodrama. Rev Bras Psicodrama. 2012; 20(2):31-7.

9. Ramos ALL. Vínculo na prática educativa escolar: um estudo com base na ludicidade e no sociodrama. Rev Bras Psicodrama. 2011; 19(2):73-84.

10. Moreno JL. Psicodrama. São Paulo: Cultrix; 2014.

11. Bardin L. Análise de conteúdo. Lisboa: Edições 70; 2012.

12. Santos EI, Gomes AMT. Vulnerability, empowerment and knowledge: nurses' memories and representations concerning care. Acta Paul Enferm. 2013; 26(5):492-8.

13. Umpiérrez AHF, Merighi MAB, Muñoz LA. Perceptions and expectations of nurses concerning their professional activity. Acta Paul Enferm. 2013; 26(2):165-71.

14. Coppus NA, Salgado JÁ, Castelani CF, Souza MD. 0 medo que temos do corpo: a psicopatologia na vida cotidiana. Analytica. 2014; 3(5):20-36.

15. Meereis ECW, Lemos LFC, Pranke GI, Alves RF, Teixeira CS, Mota CB. Deficiência visual: uma revisão focada no equilíbrio postural, desenvolvimento psicomotor e intervenções. $R$ Bras Ci Mov. 2011; 19(1):108-13.

16. Souza TA, Souza VE, Lopes MCB, Kitadai SPS. Descrição do desenvolvimento neuropsicomotor e visual de crianças com deficiência visual. Arq Bras Oftalmol. 2010; 73(6):526-30.

17. Moura GN, Nascimento JC, Lima MA, Frota NM, Cristino VM, Caetano JA. Activities of living of disabled people according to the Roper-LoganTierney model of nursing. Rev Rene. 2015; 16(3):317-26.

18. Figueiredo SV, Sousa ACC, Gomes ILV. Menores com necessidades especiais de saúde e familiares: implicações para a Enfermagem. Rev Bras Enferm. 2016; 69(1):88-95.

19. Reis AT, Santos RS, Mendes TAR. Prevalence of congenital malformations in Rio de Janeiro, Brazil, between 2000 and 2006. Rev Enferm UERJ. 2011; 19(3):123-8.

20. Marinis M. Corpo e corporeidade no teatro da semiótica às neurociências. Pequeno glossário interdisciplinar. Rev Bras Est Pre. 2012; 2(1):4261. 